University of Nebraska - Lincoln

DigitalCommons@University of Nebraska - Lincoln

Biological Systems Engineering: Papers and

Publications

Biological Systems Engineering

1993

\title{
Relative Humidity and Temperature Effects on Tensile Strength of Edible Protein and Cellulose Ether Films
}

A. Gennadios

University of Nebraska-Lincoln, aris.gennadios@catalent.com

H. J. Park

Clemson University

Curtis L. Weller

University of Nebraska-Lincoln, cweller1@unl.edu

Follow this and additional works at: https://digitalcommons.unl.edu/biosysengfacpub

Part of the Biological Engineering Commons

Gennadios, A.; Park, H. J.; and Weller, Curtis L., "Relative Humidity and Temperature Effects on Tensile Strength of Edible Protein and Cellulose Ether Films" (1993). Biological Systems Engineering: Papers and Publications. 91.

https://digitalcommons.unl.edu/biosysengfacpub/91

This Article is brought to you for free and open access by the Biological Systems Engineering at DigitalCommons@University of Nebraska - Lincoln. It has been accepted for inclusion in Biological Systems Engineering: Papers and Publications by an authorized administrator of DigitalCommons@University of Nebraska Lincoln. 


\title{
RELATIVE Humidity AND TEMPERATURE EFFECTS ON Tensile Strength of EDible Protein AND Cellulose ETHer Films
}

\author{
A. Gennadios, H. J. Park, C. L. Weller \\ MEMBER Member MEMBER \\ ASAE ASAE ASAE
}

\begin{abstract}
The effect of relative humidity and temperature on tensile strength of two types of protein-based [corn zein (CZ) and wheat gluten (WG)] and two types of cellulosic [methylcellulose (MC) and hydroxypropyl cellulose (HPC)] hydrophilic edible films was investigated. A central composite response surface design was used. Studied ranges of relative humidity and temperature were 23 to $75 \%$ and 5 to $45^{\circ} \mathrm{C}$, respectively. For all four types of films, tensile strength (TS) decreased with relative humidity and increased with temperature. Ranges of mean tensile strength values among the nine different combinations of the two variables were 5.7 to $23.6 \mathrm{MPa}, 2.7$ to $21.4 \mathrm{MPa}, 61.9$ to $104.4 \mathrm{MPa}$, and 11.1 to $35.0 \mathrm{MPa}$ for $C Z, W G, M C$, and $H P C$, respectively. A second-order polynomial model was fitted to the data with least squares regression. A regression model linear in relative humidity and quadratic in temperature showed a very good fit to tensile strength data of $C Z\left(R^{2}=0.93\right)$ and $M C\left(R^{2}=0.98\right)$ films. A regression equation linear with respect to both relative humidity and temperature satisfactorily fitted $\left(R^{2}=0.75\right)$ TS data of HPC films. A best fitted model for TS data of WG films, that included relative humidity and temperature, the square of temperature, and the cross-product of the two variables, had a poor fit $\left(R^{2}=0.67\right)$. Keywords. Wheat gluten, Corn zein, Methylcellulose, Hydroxypropyl cellulose.
\end{abstract}

1 dible films and coatings produced from renewable biological materials provide opportunities for innovative uses in food protection and preservation. Movement of moisture, gases, and solutes within food or between food and its surrounding environment can be controlled by application of edible protective layers.

Current research findings on edible film development, properties, and potential applications have been summarized in recent reviews by Kester and Fennema (1986), Guilbert (1986), Biquet (1987), and Krochta (1992). Film formation from corn, wheat, and soy proteins has been discussed in detail by Gennadios and Weller (1990 and 1991a).

Several proteins, polysaccharides, and lipid materials have been studied for development of edible films and coatings. As noted by Krochta (1992), films based on proteins and polysaccharides are very efficient oxygen and carbon dioxide barriers, whereas their resistance to water vapor transmission is limited due to their hydrophilic

Article has been reviewed and approved for publication by the Food and Process Engineering Inst. of ASAE. Presented as ASAE Paper No. 92-6019.

This research was supported by a South Carolina Agricultural Experiment Station Enhancement in Packaging Research Competitive Grant. Technical Contribution No. 3324 of the South Carolina Agricultural Experiment Station, Clemson University, Clemson, SC.

The authors are Aristippos Gennadios, Graduate Research Assistant, Dept. of Biological Systems Engineering, University of Nebraska, Lincoln (formerly with the Dept. of Agricultural and Biological Engineering, Clemson University, Clemson, SC); Hyun Jin Park, Research Associate, Dept. of Agricultural and Biological Engineering, Clemson University, Clemson, SC; and Curtis L. Weller, Assistant Professor, Dept. of Biological Systems Engineering, University of Nebraska, Lincoln (fomerly with the Dept. of Agricultural and Biological Engineering, Clemson University, Clemson, SC). nature. Lipid films are moisture resistant but their mechanical properties are inferior to those of protein and polysaccharide films. Multicomponent films have also been made in an effort to combine advantages of the individual film-forming materials.

Proteins investigated for film formation include collagen, gelatin, keratin, CZ, WG, soy protein isolate, peanut protein, casein, and whey proteins. Polysaccharide film-forming materials include cellulose derivatives, alginates, pectin, carrageenan, and starch derivatives. Substances utilized in lipid coatings include acetylated glycerides, fatty acids, and various waxes, such as beeswax, paraffin wax, carnauba wax, rice bran wax, and candelilla wax.

A number of edible films and coatings have found commercial application. Waxes are applied on fresh fruits and vegetables to replace their natural wax coating removed during washing at packing plants (Hartman and Isenberg, 1956; Kaplan, 1986). Sausage casings from collagen are manufactured and used in the place of traditional natural casings from slaughtered animals (Hood, 1987; Rust, 1987). The CZ-based solutions are commercially available for coating nutmeats and confectionery products (Alikonis, 1979; Andres, 1984). Protein-lipid films ("yuba", "soymilk skin") formed on the surface of heated soymilk have been traditionally utilized in the Far East for wrapping meats and vegetables prior to cooking (Wang, 1981; Snyder and Kwon, 1987).

Much of the information on edible films and coatings originates from the patent literature. As a consequence, quantitative data on film properties are limited. The TS is an important mechanical property of films. It expresses the maximum load developed while subjecting a film specimen to a tensile test divided by the original 
cross-sectional area of the specimen. A few studies have reported testing of edible films for TS.

TS values have been determined for $\mathrm{CZ}$ films (Takenaka et al., 1967; Aydt et al., 1991; Park et al., 1992a), wheat protein films (Wall and Beckwith, 1969; Watanabe and Okamoto, 1976; Gennadios et al., 1990; Aydt et al., 1991; Gennadios et al., 1991; Park et al., 1992a), soy protein films (Wu and Bates, 1973; Okamoto, 1978; Brandenburg et al., 1992), peanut protein films (Aboagye and Stanley, 1985), and commercial sausage casings from collagen (Hood, 1987). The MC and HPC cellulose films were evaluated for TS by Park et al. (1992b). TS values of MC films were also reported by Takenaka et al. (1967).

In some of the above studies, testing was performed after conditioning the materials at specific relative humidity (RH) and temperature (T) conditions. For example, conditioning prior to testing for two days at $50 \%$ $\mathrm{RH}$ and $25^{\circ} \mathrm{C}$ was practiced by Gennadios et al. (1990 and 1991), Park et al. (1992a and 1992b), and Brandenburg et al. (1992). In other cases no information on pretesting conditioning of specimens was provided (Wall and Beckwith, 1969; Okamoto, 1978; Hood, 1987).

Films based on protein and cellulose ethers are moisture sensitive due to the hydrophilicity of these film-forming materials. Properties of such films are dependent on their moisture content. Both $\mathrm{RH}$ and $\mathrm{T}$ are two environmental factors that determine the amount of water absorbed by hydrophilic films and, consequently, affect film properties.

The present study was undertaken in order to investigate and quantify the effect of $\mathrm{RH}$ and $\mathrm{T}$ on TS of two protein films (CZ and WG) and two cellulose ether films (MC and $\mathrm{HPC}$ ) by using response surface experimentation,

\section{Materials AND METHODS EXPERIMENTAL DESIGN}

A response surface experiment was designed to identify the relationship between two environmental variables (RH and $T$ ) and a film mechanical property (TS). The specific experimental design adopted in this study was a central composite response surface design (Box and Draper, 1987). RH and $T$ were independent variables (factors), while TS was a dependent variable (response). Coded and natural values for the levels of the independent variables are shown in table 1. Variables were coded using the following transformation:

$$
\mathrm{X}_{\mathrm{C}}=\left(\mathrm{X}_{\mathrm{N}}-\mathrm{X}_{\mathrm{B}}\right) / \mathrm{J}
$$

where

$\mathrm{X}_{\mathrm{C}} \quad$ - the coded value of the factor

$X_{N}=$ the natural value of the factor

$X_{B}=$ the natural value of the basic level (center point)

$\mathrm{J}=$ the variation interval

Variation intervals were set at $12.5 \%$ for $\mathrm{RH}$ and $10^{\circ} \mathrm{C}$ for $\mathrm{T}$.

Nine level combinations were included in the constructed design (table 2). The center point $(0,0$ or $50 \%$ $\mathrm{RH}$ and $25^{\circ} \mathrm{C}$ ) was replicated five times. Replicated points at the design center offer an estimation of the experimental error.
Table 1. Levels of independent variables in the experimental design

\begin{tabular}{ccc}
\hline Relative \\
Code & $\begin{array}{c}\text { Humidity }\left(X_{1}\right) \\
(\%)\end{array}$ & $\begin{array}{c}\text { Temperature }\left(X_{2}\right) \\
\left({ }^{\circ} \mathrm{C}\right)\end{array}$ \\
\hline-2 & 25 & 5 \\
-1 & 38 & 15 \\
0 & 50 & 25 \\
1 & 62 & 35 \\
2 & 75 & 45 \\
\hline
\end{tabular}

Responses $Y_{i}$ for each experimental point were means of 10 replicates. The following second order polynomial model consisting of two linear, one interaction, and two quadratic terms was fitted with regression to the obtained responses:

$$
\begin{aligned}
Y & =b_{0}+b_{1} X_{1}+b_{2} X_{2}+b_{11} X_{1}^{2} \\
& +b_{22} X_{2}^{2}+b_{12} X_{1} X_{2}
\end{aligned}
$$

where $b$ values are the regression coefficients and $X_{1}$ and $\mathrm{X}_{2}$ are the coded independent variables.

All statistical calculations were performed using the SAS/STAT ${ }^{\text {TM }}$ statistical package (SAS Institute, Inc., 1988).

\section{REAGENTS}

The CZ protein (F-4000) was donated by Freeman Industries, Tuckahoe, New York. Vital WG protein (DOPEP) was donated by ADM Arkady, Olathe, Kansas. Both MC (viscosity $25 \mathrm{cp}$ ) and HPC (molecular weight $1,000,000$ ) were obtained from Aldrich Chemical Company, Inc., Milwaukee, Wisconsin. Glycerol (USP grade), potassium carbonate, and potassium acetate were purchased from Baxter Diagnostics, Inc., McGaw Park, Illinois. Magnesium chloride was bought from Fisher

Table 2. Level combinations of independent variables included in the experimental design

\begin{tabular}{cccccc}
\hline & \multicolumn{2}{c}{ Level of $\mathrm{X}_{1}^{*}$} & & \multicolumn{2}{c}{ Level of $\mathrm{X}_{2}{ }^{*}$} \\
\cline { 2 - 3 } \cline { 5 - 6 } Design Point & Coded & Natural & & Coded & Natural \\
\hline 1 & $-1 \dagger$ & $38 \dagger$ & & -1 & 15 \\
2 & -1 & 38 & & 1 & 35 \\
3 & 1 & 62 & & -1 & 15 \\
4 & 1 & 62 & & 1 & 35 \\
5 & 2 & 75 & & 0 & 25 \\
6 & $-2 \ddagger$ & $25 \ddagger$ & & 0 & 25 \\
7 & 0 & 50 & & 2 & 45 \\
8 & $0 \$$ & $50 \S$ & & -2 & 5 \\
91 & 0 & 50 & & 0 & 25 \\
\hline
\end{tabular}

* Variables $X_{1}$ and $X_{2}$ are relative humidity (\%) and temperature $\left({ }^{\circ} \mathrm{C}\right)$, respectively.

$\dagger$ An actual value of $-1.36(33 \%)$ was obtained in the lab and used in the calculations.

$\doteqdot$ An actual value of $-2.16(23 \%)$ was obtained in the lab and used in the calculations.

$\S$ An actual value of $-0.16(48 \%)$ was obtained in the lab and used in the calculations.

I) This design point (center point) was repeated five times. 
Scientific, Pittsburgh, Pennsylvania. Ammonium hydroxide $(5 \mathrm{~N})$ and $95 \%$ ethanol were obtained from Aldrich Chemical Company, Inc.

\section{Preparation of Film-Forming Solutions}

The CZ film-forming solutions were prepared by dissolving $54 \mathrm{~g}$ of protein into $325 \mathrm{~mL}$ of $95 \%$ ethanol. Glycerol $(18 \mathrm{~mL})$, which is necessary for film plasticization, was subsequently added to the solutions.

Film-forming solutions for WG films were prepared by mixing $75 \mathrm{~g}$ of protein, $360 \mathrm{~mL}$ of $95 \%$ ethanol, and $228 \mathrm{~mL}$ of distilled water. Glycerol $(21 \mathrm{~mL})$ and $5 \mathrm{~N}$ ammonium hydroxide $(72 \mathrm{~mL})$ were subsequently added and the solutions were homogenized (Virtishear ${ }^{\circledR}$, The Virtis Company, Inc., Cardiner, NY) at 6,000 rpm for $5 \mathrm{~min}$ and filtered through cheese cloth. For the two cellulosic films $9 \mathrm{~g}$ of MC or HPC were dissolved into $200 \mathrm{~mL}$ of $95 \%$ ethanol and $100 \mathrm{~mL}$ of distilled water. Both types of solutions were homogenized at $6,000 \mathrm{rpm}$ for $5 \mathrm{~min}$.

Prior to pouring, all four types of solutions were conditioned for $15 \mathrm{~min}$ in a waterbath (Versa-Bath ${ }^{\circledR} \mathrm{S}$, Model 236, Fischer Scientific, Pittsburgh, PA) maintained at $80^{\circ} \mathrm{C}$.

\section{Pouring and Drying of Film-Forming Solutions}

Film-forming solutions were poured and evenly spread on leveled glass plates $(24 \mathrm{~cm} \times 24 \mathrm{~cm})$. The amount of liquid poured on the glass surface was $80 \mathrm{~mL}$ for $\mathrm{CZ}$ and WG films and $200 \mathrm{~mL}$ for MC and HPC films. Solutions on the plates were allowed to settle for $15 \mathrm{~min}$ and subsequently they were placed for $30 \mathrm{~min}$ in a drying oven (Isotemp®, model 338F, Fisher Scientific, Pittsburgh, PA) set at $55^{\circ} \mathrm{C}$. At the end of the 30-min drying period, plates were taken out of the oven, films were peeled off, and specimens for TS testing were cut.

\section{THICKNESS}

Film thickness was determined to the nearest $2.54 \mu \mathrm{m}$ (0.1 mil) with a hand-held micrometer (B.C. Ames Co., Waltham, MA). Thickness values reported for each film type represent a mean of 130 measurements.

\section{Film Conditioning}

For all experimental points, film specimens were stored under the specified RH and T conditions for two days. An environmental chamber (model 317332, Hotpack, Corp., Philadelphia, PA) was used to achieve required conditions for all design points except Nos. 1, 6, and 8 (table 2). These three points did not fall within the operation range of the chamber.

Portable desiccator cabinets containing appropriate saturated salt solutions were used for design points 1,6 , and 8. Magnesium chloride, potassium acetate, and potassium carbonate saturated salt solutions were used for points 1,6 , and 8 , respectively. The RH values obtained by using magnesium chloride, potassium acetate, and potassium carbonate were $33 \%, 23 \%$, and $48 \%$, respectively (Rockland, 1960). These values slightly deviated from respective targeted values of $38 \%, 25 \%$, and $50 \%$. Adjusted RH coded values of -1.36 (point 1 ), -2.16 (point 6), and -0.16 (point 8 ) were used in the calculations in place of theoretical values $-1,-2$, and 0 , respectively, to account for these deviations.

The desiccators were kept in an environmental chamber set at the desired temperatures and 50\% RH. For point 6 , desiccators were placed in the same chamber mentioned earlier, whereas a second chamber (model 790-001, LabLine Instruments, Inc., Melrose Park, IL) was used for points 1 and 8 .

\section{MEASUREMENT OF TS}

An Instron Universal Testing Instrument (model 4201, Instron Engineering Corp., Canton, MA) was used to determine film TS. Initial grip separation and crosshead speed were set at $50 \mathrm{~mm}$ and $500 \mathrm{~mm} / \mathrm{min}$, respectively. Calculations were performed as described by Gennadios et al. (1990 and 1991). Tested film specimens were rectangular strips $100-\mathrm{mm}$ long and $25.4-\mathrm{mm}$ wide as suggested in ASTM Standard Method D 882-88 (ASTM, 1989).

\section{RESULTS AND DisCUSSION}

\section{Film THickNeSS AND ELONGation}

Mean thicknesses of prepared films were 141, 106, 57, and $54 \mu \mathrm{m}$ for $\mathrm{CZ}, \mathrm{WG}, \mathrm{MC}$, and HPC films, respectively. The range of thickness measurements was within $40 \%$ of mean values for each of the four types of films.

Elongation at break values were also recorded for film specimens subjected to tensile test. While film thickness is accounted for in the calculations of TS, this is not the case with elongation. As a result, comparisons in terms of elongation are meaningful only for films of practically equal thickness. Due to thickness variability of the four types of films in this study, elongation values were not statistically analyzed in a manner similar to the TS values. At the center experimental point $\left(50 \% \mathrm{RH}, 25^{\circ} \mathrm{C}\right)$ elongation at break values had ranges of 3 to $7 \%, 100$ to $280 \%, 8$ to $25 \%$, and 10 to $50 \%$ for CZ, WG, MC, and HPC films, respectively.

\section{EFFect of Relative Humiti}

Mean TS values of the four types of films at each combination of independent variables are shown in table 3. Three-dimensional plots of TS with respect to RH and T including predicted data points generated by the SAS statistical package are shown in figures $1,2,3$, and 4 . As the figures show, a decrease in TS was evidenced when RH increased for all four types of films. This was concluded to result from increasing film moisture content with RH. As shown in table 4 , substantial increases in equilibrium moisture content with increases in $\mathrm{RH}$ have been documented for hydrophilic $\mathrm{CZ}, \mathrm{WG}, \mathrm{MC}$, and HPC films.

Absorbed moisture has a plasticizing effect on hydrophilic films, such as films from proteins and cellulose ethers (Ashley, 1985). Consequently, tensile strength and barrier properties of such films are negatively affected by moisture uptake.

\section{EFFECT OF TEMPERATURE}

The effect of T was opposite to that of RH. That is, TS values increased with temperature for all four types of films (figs. 1, 2,3, and 4). This behavior is also concluded to be related to film moisture content. In general, at 
Table 3. The TS values of $\mathrm{CZ}, \mathrm{WG}, \mathrm{MC}$, and $\mathrm{HPC}$ films conditioned for two days at various sets of $R H$ and $T$

\begin{tabular}{|c|c|c|c|c|c|c|}
\hline \multirow{2}{*}{$\begin{array}{c}\text { Design } \\
\text { Point }\end{array}$} & \multirow{2}{*}{$\begin{array}{l}\mathrm{RH} \\
(\%)\end{array}$} & \multirow{2}{*}{$\begin{array}{c}\mathrm{T} \\
\left({ }^{\circ} \mathrm{C}\right)\end{array}$} & \multicolumn{4}{|c|}{ Tensile Strength (MPa) } \\
\hline & & & $\mathrm{CZ}^{*}$ & WG* & $\mathrm{MC}^{*}$ & $\mathrm{HPC}^{*}$ \\
\hline 1 & 33 & 15 & $12.5 \pm 1.3 \mathrm{de}$ & $3.8 \pm 0.6 \mathrm{e}$ & $70.2 \pm 3.3 \mathrm{f}$ & $23.7 \pm 2.3 \mathrm{c}$ \\
\hline 2 & 38 & 35 & $17.1 \pm 1.2 \mathrm{e}$ & $21.4 \pm 2.8 \mathrm{a}$ & $96.7 \pm 4.1 \mathrm{~b}$ & $35.0 \pm 1.7 \mathrm{a}$ \\
\hline 3 & 62 & 15 & $7.9 \pm 0.8 \mathrm{~g}$ & $2.7 \pm 0.3 \mathrm{f}$ & $66.0 \pm 3.9 \mathrm{~g}$ & $11.1 \pm 0.8 \mathrm{f}$ \\
\hline 4 & 62 & 35 & $12.2 \pm 0.9 \mathrm{e}$ & $8.5 \pm 1.1 \mathrm{c}$ & $92.2 \pm 6.1 \mathrm{c}$ & $29.4 \pm 3.0 \mathrm{~b}$ \\
\hline 5 & 75 & 25 & $5.7 \pm 0.5 \mathrm{~h}$ & $2.7 \pm 0.6 \mathrm{f}$ & $72.3 \pm 2.6 \mathrm{f}$ & $17.6 \pm 1.6 \mathrm{e}$ \\
\hline 6 & 23 & 25 & $19.5 \pm 2.0 \mathrm{~b}$ & $5.2 \pm 0.7 \mathrm{~d}$ & $84.5 \pm 3.3 \mathrm{~d}$ & 24.4 \\
\hline 7 & 50 & 45 & $23.6 \pm 1.1 \mathrm{a}$ & $12.1 \pm 1.0 \mathrm{~b}$ & $104.4 \pm 3.4 \mathrm{a}$ & $30.1 \pm 1.5 \mathrm{~b}$ \\
\hline 8 & 48 & 5 & $10.6 \pm 1.1 f$ & $3.3 \pm 0.3 \mathrm{ef}$ & $61.9 \pm 2.1 \mathrm{~h}$ & $16.3 \pm 1.7 \mathrm{e}$ \\
\hline 9 & 50 & 25 & $13.3 \pm 1.6 \mathrm{de}$ & $3.8 \pm 0.3 \mathrm{e}$ & $80.4 \pm 4.3 \mathrm{de}$ & $19.8 \pm 1.9 \mathrm{~d}$ \\
\hline 10 & 50 & 25 & $13.6 \pm 1.5 \mathrm{~d}$ & $3.9 \pm 0.5 \mathrm{e}$ & $77.6 \pm 4.3 \mathrm{e}$ & $20.8 \pm 1.7 \mathrm{~d}$ \\
\hline 11 & 50 & 25 & $12.8 \pm 1.3 \mathrm{de}$ & $3.9 \pm 0.3 \mathrm{e}$ & $79.2 \pm 4.6 \mathrm{e}$ & $20.7 \pm 1.6 \mathrm{~d}$ \\
\hline 12 & 50 & 25 & $12.8 \pm 1.1 \mathrm{de}$ & $3.8 \pm 0.3 \mathrm{e}$ & $76.3 \pm 4.3 \mathrm{e}$ & $19.5 \pm 2.0 \mathrm{~d}$ \\
\hline 13 & 50 & 25 & $13.5+1.7 \mathrm{de}$ & $3.8 \pm 0.4 \mathrm{e}$ & $80.4 \pm 4.5 \mathrm{de}$ & $20.0 \pm 1.5 \mathrm{~d}$ \\
\hline
\end{tabular}

* The TS values are means of 10 replicates plus/minus one standard deviation. Any two means followed by the same small case letter are not significantly different at $\alpha=0.05$ level of significance according to Duncan's New Multiple-Range Test.

constant relative humidity the amount of water absorbed by food materials decreases with an increase in temperature (Labuza, 1968; Labuza, 1984). Therefore, more water was bound at lower temperatures increasing film plasticizing and causing weakening.

For instance, equilibrium moisture content of WG protein at $42 \% \mathrm{RH}$ was measured as, approximately, 0.088 , 0.086 , and $0.082 \mathrm{~g}$ moisture/g dry solids at $20.2^{\circ}, 30.1^{\circ}$, and $40.8^{\circ} \mathrm{C}$, respectively (Bushuk and Winkler, 1957). The MC and HPC films had equilibrium moisture contents of 0.08 and $0.06 \mathrm{~g}$ moisture $/ \mathrm{g}$ dry solids at $21^{\circ} \mathrm{C}$, whereas these values increased to 0.13 and $0.08 \mathrm{~g}$ moisture/g dry solids, respectively, at $5^{\circ} \mathrm{C}$ (Park, 1991).

\section{Model FitTing to CZ Films}

Mean TS values of $\mathrm{CZ}$ films ranged from 5.7 to 23.6 MPa among the 13 different experimental points (table 3). Fitting of the second order polynomial model showed that two terms, the square of $\mathrm{RH}$ and the crossproduct $R H \cdot T$, were insignificant $(P<0.05)$.

A reduced regression model fitted after omitting these two terms had a very good fit $\left(R^{2}=0.93\right)$, The F-value

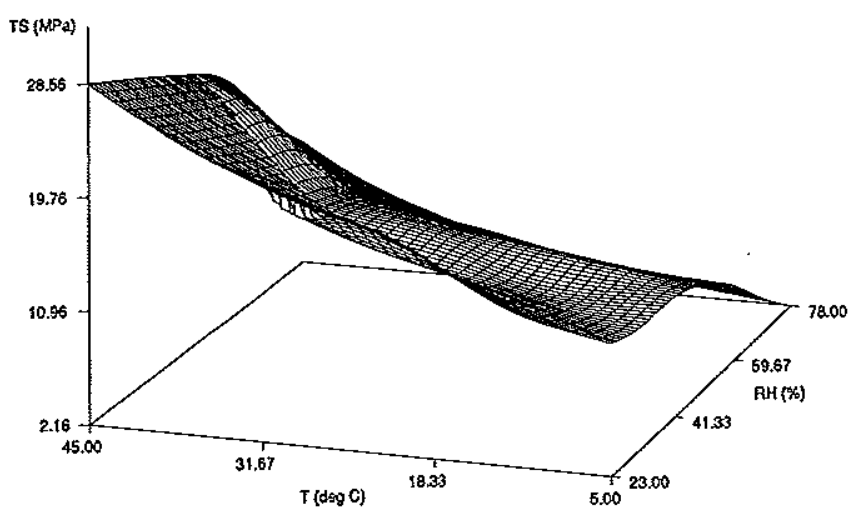

Figure 1-Plot of TS values of $\mathrm{CZ}$ films with respect to conditioning RH and $T$.

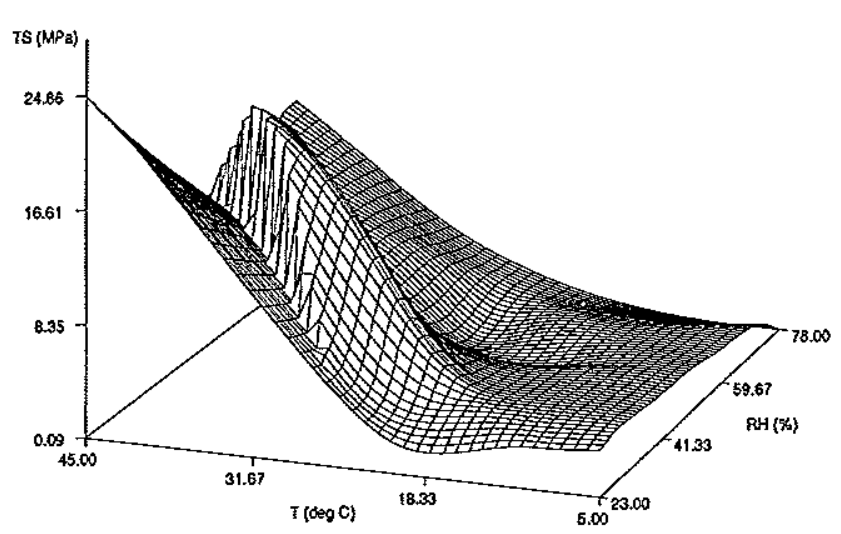

Figure 2-Plot of TS values of wheat gluten films with respect to conditioning $\mathrm{RH}$ and $\mathrm{T}$.

(41.9) calculated for the regression was significant $(P<0.01)$ indicating that an important amount of the variation can be explained by the regression model.

Therefore, TS of CZ films exhibited a linear dependence on $\mathrm{RH}$ and a quadratic dependence on $\mathrm{T}$. The best fitted prediction equation had the form:

$$
\mathrm{TS}=12.468-2.888 \cdot \mathrm{RH}+3.071 \cdot \mathrm{T}+0.952 \cdot \mathrm{T}^{2}
$$

\section{Model Fitring to WG Films}

WG films had TS values between 2.7 and $21.4 \mathrm{MPa}$ (table 3). Fit of the second order model was poor with an insignificant $(\mathrm{P}<0.1) \mathrm{F}$-value for regression. An improvement was noticed (regression $\mathrm{F}$-value significant at $\mathrm{P}<0.05$ ) by dropping the term $\mathrm{RH}^{2}$ from the model. The best fitted regression equation $\left(R^{2}=0.67\right)$ was:

$$
\begin{aligned}
\mathrm{TS} & =5.091-1.605 \cdot \mathrm{RH}+3.299 \cdot \mathrm{T} \\
& +1.103 \cdot \mathrm{T}^{2}-2.568 \cdot \mathrm{RH} \cdot \mathrm{T}
\end{aligned}
$$

$\mathrm{T}$ in the above model was significant at $\mathrm{P}<0.05$, whereas $\mathrm{RH}, \mathrm{T}^{2}$, and $\mathrm{RH} \cdot \mathrm{T}$ were significant at $\mathrm{P}<0.2$. Probably a power model is necessary to describe adequately TS dependence on RH and $T$ for WG films.

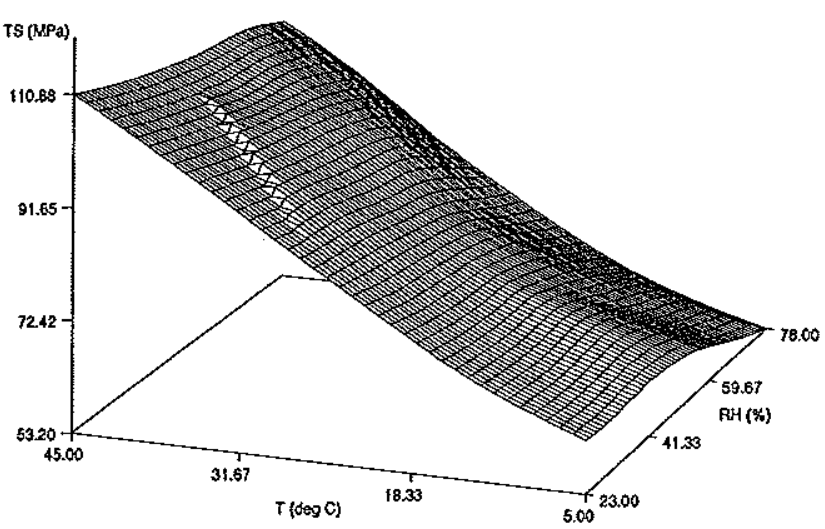

Figure 3-Plot of TS values of $\mathrm{MC}$ films with respect to conditioning RH and T. 


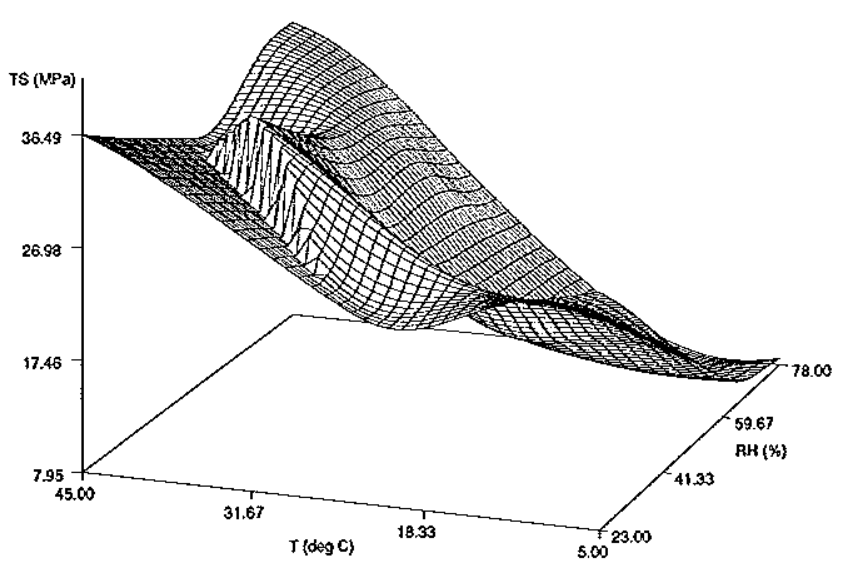

Figure 4-Plot of TS values of HPC films with respect to conditioning RH and $T$.

\section{Model FitTing to MC Films}

Mean TS values for MC films ranged from 61.9 to 104.4 MPa among the nine level combinations (table 3). Analysis of variance for the fitted original model showed that the interaction term $(\mathrm{RH} \cdot \mathrm{T})$ and the square of $\mathrm{RH}$ were insignificant $(\mathrm{P}<0.1)$.

A reduced model fitted after dropping these two terms had an excellent fit to the data $\left(R^{2}=0.98\right.$, regression F-value significant at $\mathrm{P}<0.01$ ). Both $\mathrm{RH}$ and $\mathrm{T}$ were significant at $\mathrm{P}<0.01$, while $\mathrm{T}^{2}$ was significant at $\mathrm{P}<0.05$. The best fitted model, linear with respect to $\mathrm{RH}$ and quadratic with respect to $T$, was as follows:

$$
\mathrm{TS}=79.003-2.566 \cdot \mathrm{RH}+11.607 \cdot \mathrm{T}+1.100 \cdot \mathrm{T}^{2}
$$

\section{MODEL FITTING TO HPC FILMS}

HPC films had mean TS values between 11.1 and 35.0 MPa at the different level combinations studied (table 3). These values were substantially lower than TS values of MC films. The high level of hydroxypropyl substitution in HPC causes internal plasticizing effects and results in films weaker than MC films (Krumel and Lindsay, 1976).

Both quadratic terms, as well as the interaction term in the original second order model were insignificant $(\mathrm{P}<0.1)$. A reduced model linear in both $\mathrm{T}(\mathrm{P}<0.01)$ and $\mathrm{RH}(\mathrm{P}<0.05)$ gave a reasonably good fit $\left(\mathrm{R}^{2}=0.75\right.$, regression $\mathrm{F}$-value significant at $\mathrm{P}<0.01$ ). This best fitted equation had the form:

$$
\mathrm{TS}=22.063-2.601 \cdot \mathrm{RH}+4.926 . \mathrm{T}
$$

Table 4. Equilibrium moisture content of CZ, WG, MC, and $H P C$ films at different $R H$ values

\begin{tabular}{ccccc}
\hline & \multicolumn{4}{c}{ Moisture Content (g H $\mathrm{O}_{2} \mathrm{O}$ g dry solids) } \\
\cline { 2 - 5 } RH (\%) & CZ Films* & WG Films* & MC Filmsł & HPC Films \\
\hline 33 & 0.02 & 0.06 & 0.05 & 0.04 \\
53 & 0.06 & 0.12 & 0.08 & 0.06 \\
75 & 0.15 & 0.28 & 0.15 & 0.12 \\
\hline
\end{tabular}

* From Gennadios and Weller (1991b) at $25^{\circ} \mathrm{C}$.

$\dagger$ From Park $(1991)$ at $21^{\circ} \mathrm{C}$.

\section{FiLM Hydrophilicity}

Using as a criterion the ratio of the lowest TS value over the highest TS value among the nine different environmental combinations tested, we concluded that variations in $\mathrm{RH}$ and $\mathrm{T}$ affect WG films more than they affect $\mathrm{CZ}$ films (the ratios were 0.13 and 0.24 for $\mathrm{WG}$ and CZ films, respectively).

This may be explained by the more hydrophobic nature of CZ protein than that of WG. Belitz et al. (1986) calculated an average $\mathrm{CZ}$ hydrophobicity of $1,263 \mathrm{cal} / \mathrm{mol}$, while average hydrophobicities of wheat gliadin and wheat glutenin, the two major fractions of WG, were 1,047 and $955 \mathrm{cal} / \mathrm{mol}$, respectively.

Similar lowest/highest TS value ratios for MC and HPC films were 0.59 and 0.32 , respectively, suggesting that $\mathrm{MC}$ films are more sensitive than HPC films to variations of $\mathrm{RH}$ and $\mathrm{T}$. This was expected considering the greater relative hydrophilicity of MC in comparison with HPC (Krumel and Lindsay, 1976).

\section{IMPLICATIONS}

Envisioned packaging applications for hydrophilic protein and cellulose ether films include use of such films in multilayer packages in the place of currently used moisture-sensitive polymeric materials; employment of protein and cellulosic coatings as carriers of antioxidants and other food additives; and development of edible protective coatings for use on food items that require films of high water vapor permeability (e.g., meat pies; highmoisture, low-sugar cakes).

A thorough knowledge of film properties is needed for tailoring protein and cellulose ether films to such applications. It was evidenced in the present study that relative humidity and temperature, factors that affect film moisture absorption, substantially influenced film TS, an important mechanical property. Consequently, property testing of hydrophilic protein and cellulosic films at the anticipated conditions of use is essential for proper prediction of film performance. Empirical models, similar to the models developed in the present study, can allow for estimates of film properties at specific relative humidity and temperature conditions.

\section{REFERENCES}

Aboagye, Y. and D. W. Stanley. 1985. Texturization of peanut proteins by surface film formation. 1 . Influence of process parameters on film forming properties. Can. Inst. Food Sci. Technol. J. 18:12-20.

Alikonis, J. J. 1979. Candy Technology. Westport, CT: The Avi Publishing Company, Inc.

Andres, C. 1984. Natural edible coating has excellent moisture and grease barrier properties. Food Process. 45(13):48-49.

Ashley, R. J. 1985. Permeability and plastics packaging. In Polymer Permeability, ed. J. Comyn, 269-308. London: Elsevier Applied Science Publishers, Ltd.

ASTM. 1989. Annual Book of ASTM Standards. Philadelphia, PA: American Society for Testing and Materials.

Aydt, T. P., C. L. Weller and R. F. Testin. 1991. Mechanical and barrier properties of edible corn and wheat protein films. Transactions of the ASAE 34(1):207-211.

Belitz, H. D., R. Kieffer, W. Seilmeier and H. Wieser, 1986. Structure and function of gluten proteins. Cereal Chem. 63:336-341. 
Biquet, B. 1987. Moisture transfer in foods and edible moisture barriers. M.S. thesis, University of Minnesota, St. Paul.

Box, G. E. P. and N. R. Draper. 1987. Empirical Model-building and Response Surfaces. New York: John Wiley \& Sons, Inc.

Brandenburg, A. H., C. L. Weller and R. F. Testin. 1992. Edible films and coatings from soy protein. Paper No. 429, presented at 52nd Annual Meeting of Institute of Food Technologists, New Orleans, LA, June 20-24.

Bushuk, W. and C. A. Winkler, 1957. Sorption of water vapor on wheat flour, starch, and gluten. Cereal Chem. 34:73-86.

Gennadios, A, and C. L. Weller. 1990. Edible films and coatings from wheat and com proteins. Food Technol. 44(10):63-69. 1991a. Edible films and coatings from soymilk and soy protein. Cereal Foods World 36:1004-1009. 1991b. Moisture sorption isotherms of edible films. ASAE Paper No. 91-6521. St. Joseph, MI: ASAE.

Gennadios, A., C. L. Weller and R, F. Testin. 1990. Modification of properties of edible wheat gluten films. ASAE Paper No. 90-6504. St. Joseph, MI: ASAE. 1991. Modification of physical and barrier properties of edible wheat gluten-based films. Paper No. VIIIB.6, presented at the 1991 Conference of Food Engineering, American Institute of Chemical Engineers, Chicago, IL, March 10-12.

Guilbert, S. 1986. Technology and application of edible protective films. In Food Packaging and Preservation, ed. M. Mathlouthi, 371-394. London: Elsevier Applied Science Publishers.

Hartman, J. D. and F. M. Isenberg. 1956. Waxing vegetables. Comell Extension Bulletin 965. Comell University, Ithaca, NY.

Hood, L. L. 1987. Collagen in sausage casings. Adv. Meat Res. 4:109-129.

Kaplan, H. J. 1986. Washing, waxing, and color-adding. In Fresh Citrus Fruits, ed. W. F. Wardowski, S. Nagy and W. Grierson, 379-395. Westport, CT: The Avi Publishing Company, Inc.

Kester, J. J. and O. Fennema. 1986. Edible films and coatings: A review. Food Technol. 40(12):47-59.

Krochta, J. M. 1992. Control of mass transfer in foods with edible coatings and films. In Advances in Food Engineering (In press). Boca Raton, FL: CRC Press, Inc.

Krumel, K. L. and T. A. Lindsay. 1976. Nonionic cellulose ethers. Food Technol. 30(4):36-38, 40, 43.

Labuza, T. P. 1968. Sorption phenomena in foods. Food Technol. 22(3):15-17, 20, 22, 24
Labuza, T. P. 1984. Moisture Sorption: Practical Aspects of Isotherm Measurement and Use. St. Paul, MN: American Association of Cereal Chemists.

Okamoto, S. 1978. Factors affecting protein film formation. Cereal Foods World 23(5):256-262.

Park, H. J. 1991. Edible coatings for fruits and vegetables: Determination of gas diffusivities, prediction of internal gas composition and effects of the coating on the shelf life. Ph.D. thesis, University of Georgia, Athens.

Park, H. J., C. L. Weller, P. J. Vergano and R. F. Testin. 1992a. Factors affecting barrier and mechanical properties of proteinbased edible, degradable films. Paper No. 428, presented at 52nd Annual Meeting of Institute of Food Technologists, New Orleans, LA, June 20-24.

Park, H. J., C. L. Weller, P. J. Vergano and R. F. Testin. 1992b. Barrier and mechanical properties of cellulose films based on molecular weight. Paper presented at 89 th Annual Meeting of the Southern Association of Agricultural Scientists, Lexington, KY, February 2-5.

Rockland, L. B. 1960. Saturated salt solutions for static control of relative humidity between 50 and $40^{\circ} \mathrm{C}$. Analyt. Chem. 32:1375-1376.

Rust, R. E. 1987. Sausage products. In The Science of Meat and Meat Products, eds. J. F. Price and B. S. Schweigert, 457-485. Westport, CT: Food and Nutrition Press, Inc.

SAS Institute, Inc. 1988. SAS/STAT ${ }^{M}$ User's Guide, Release 6.03 Edition. Cary, NC.

Snyder, H. E. and T. W. Kwon, 1987. Soybean Utilization. New York: Van Nostrand Reinhold.

Takenaka, H., H. Ito, H. Asano and H. Hattori. 1967. On some physical properties of film forming materials. Gifu Yakka Daigaku 17:142-146.

Wall, J. S. and A. C. Beckwith, 1969. Relationship between structure and theological properties of gluten proteins. Cereal Sci. Today 14(1):16-18, 20-21.

Wang, H, L. 1981. Oriental soybean foods. Food Dev. 15(5):2934.

Watanabe, K. and S. Okamoto. 1976. Formation of yuba-like films and their physical properties. New Food Industry 18(4):65-77.

Wu, L. C. and R. P. Bates. 1973. Influence of ingredients upon edible protein-lipid film characteristics. J. Food Sci. 38:783787. 